\title{
PERSEPSI DAN PARTISIPASI NELAYAN \\ DALAM PENGELOLAAN DAERAH PERLINDUNGAN LAUT SEKUNYIT KABUPATEN KAUR PROVINSI BENGKULU
}

\author{
Andrias Koko $^{1)}$, Agus Susatya ${ }^{2)}$, Enggar Apriyanto ${ }^{2)}$ \\ ${ }^{1)}$ Program Pascasarjana Pengelolaan Sumber Daya Alam dan Lingkungan, Fakultas \\ Pertanian, Universitas Bengkulu \\ ${ }^{1)}$ Dinas Kelautan dan Perikanan Provinsi BengkuluKota Bengkulu \\ ${ }^{2)}$ Jurusan Kehutanan Fakultas Pertanian Universitas Bengkulu
}

\begin{abstract}
ABSTRAK
Pada wilayah pesisir Desa Sekunyit terdapat program pengelolaan wilayah pesisir dengan menggunakan pendekatan konservasi terhadap terumbu karang yang dinamakan Daerah Perlindungan Laut (DPL) pada tahun 2009. Daerah Perlindungan Laut Sekunyit terletak di Desa Sekunyit, Kecamatan Kaur Selatan, Kabupaten Kaur, Provinsi Bengkulu. Tujuan penelitian ini adalah mengkaji persepsi dan partisipasi nelayan, serta mengetahui hubungan antara persepsi nelayan terhadap partisipasi nelayan dalam pengelolaan DPL Sekunyit. Variabel penelitian adalah variabel persepsi (dengan parameter 12 pertanyaan) dan partisipasi nelayan (dengan parameter 10 pertanyaan). Variabel persepsi nelayan dipisahkan dalam 3 (tiga) kategori, yaitu baik, sedang dan tidak baik. Variabel partisipasi nelayan juga dibagi menjadi 3 (tiga) kategori, yaitu aktif, pasif, dan negatif. Data yang digunakan meliputi data primer (data yang diperoleh melalui pengamatan, kuisioner dan hasil wawancara) dan data sekunder (berasal dari monografi desa dan instansi terkait). Jumlah responden sebanyak 50 orang $(24,27 \%)$ dari jumlah penduduk yang berprofesi sebagai nelayan (206 orang). Metode analisis yang digunakan adalah analisis deskriptif kuantitatif. Hasil penelitian menunjukkan bahwa nelayan Desa Sekunyit mempunyai tingkat persepsi baik $(72,42 \%)$ dan tingkat partisipasi akif $(70,10 \%)$ dalam pengelolaan DPL Sekunyit. Uji Chi Square menunjukkan bahwa tidak ada hubungan yang signifikan antara tingkat persepsi nelayan dengan tingkat partisipasi nelayan dalam pengelolaan DPL Sekunyit (X2 hitung 2,105 $<$ X2 tabel 3,841). Derajat keeratan hubungan antara persepsi dan partisipasi nelayan dalam pengelolaan DPL Sekunyit masuk dalam kategori rendah (C 0,201).
\end{abstract}

Kata Kunci : persepsi nelayan, partisipasi nelayan, dpl sekunyit

\section{PENDAHULUAN}

Kabupaten Kaur merupakan salah satu daerah pesisir di Provinsi Bengkulu yang terletak $\pm 250 \mathrm{~km}$ dari Kota Bengkulu, Kaur mempunyai luas 2.369,05 $\mathrm{km}^{2}$ dan dihuni sedikitnya 110.428 jiwa. Kondisi geografis, demografis, sosial ekonomi dan budaya masyarakat di wilayah pesisir secara menyeluruh memerlukan strategi pengelolaan kawasan yang lebih dititik beratkan pada pembangunan wilayah yang tepat dan sinergis dalam bentuk pola pengelolaan wilayah baik jangka pendek, menengah maupun jangka panjang sehingga pembangunan menyeluruh dapat tercapai. Usaha peningkatan aktifitas kawasan dan kegiatan ekonomi yang kurang memperhatikan aspek kelestarian ekosistem dapat menimbulkan dampak yang sangat membahayakan bagi suatu kawasan. Sebagai kawasan yang sedang berkembang Kabupaten Kaur tidak terlepas dari permasalahan pengelolaan dan pengembangannya. Semakin 
meningkatnya pertumbuhan penduduk dan pesatnya kegiatan pembangunan di wilayah pesisir seperti pemukiman, perikanan, pelabuhan, dan obyek wisata, menyebabkan tekanan ekologis terhadap ekosistem pesisir juga semakin meningkat. Setiap tahunnya terjadi penurunan kualitas dan daya dukung ekosistem pesisir dan laut karena penangkapan ikan secara destruktif dan eksploitasi Terumbu Karang.

Pada tahun 2007, Bupati Kabupaten Kaur telah mengeluarkan Surat Keputusan No.180 tahun 2007 Tanggal 20 Juni 2007 tentang penunjukan garis Pantai Linau, Merpas dan Sekunyit sebagai KKLD Kabupaten Kaur untuk mempertahankan terumbu karang dan kawasan pantai dari kerusakan. Desa Sekunyit sebagai bagian dari KKLD pada tahun 2009 oleh Mitra Bahari dan Dinas Kelautan Provinsi Bengkulu telah dilaksanakan kegiatan DPL-BM. Sebagian penduduk di daerah ini sebelum tahun 2009 masih memanfaatkan batu karang untuk membangun rumah dan jalan sehingga karang di sepanjang pinggir pantai mengalami kerusakan. Ancaman kerusakan ekosistem terumbu karang ini dikarenakan pemahaman masyarakat terhadap nilai tidak langsung (undirect use value) dari ekosistem terumbu karang masih minim. Masyarakat baru dapat melihat nilai langsung (direct use value) yang sebenarnya jauh lebih kecil. Hal ini menyebabkan masyarakat lebih memilih memanfaatkan ekosistem terumbu karang yang mengarah kepada kerusakan.

Persepsi masyarakat berkaitan dengan pemahaman nelayan terhadap sumberdaya pesisir. Pastisipasi masyarakat dalam pengelolaan DPL diperlukan dalam setiap kegiatan yang dilaksanakan, sehingga dalam pelaksanaannya masyarakat akan merasa memiliki dan bertanggung jawab dalam menjaga kelestarian sumber daya pesisir secara berkelanjutan. Persepsi dan partisipasi masyarakat merupakan hal yang harus diperhatikan dalam kegiatan pengelolaan Daerah Perlindungan Laut Desa Sekunyit karena masyarakat pesisir khususnya nelayan merupakan pihak yang pertama merasakan dampak dari degradasi lingkungan di kawasan pesisir. Berdasarkan hal tersebut, perlu dilakukan penelitian tentang persepsi dan partisipasi nelayan dalam pengelolaan DPL di Desa Sekunyit.

Tujuan dari penelitian ini adalah:

1. Mengkaji persepsi dan partisipasi nelayan setempat dalam mengelola Daerah Perlindungan Laut.

2. Mengetahui hubungan antara persepsi nelayan dengan partisipasi nelayan dalam pengelolaan Daerah Perlindungan Laut.

\section{METODE PENELITIAN}

Penelitian ini dilaksanakan di Desa Sekunyit Kecamatan Kaur Selatan Kabupaten Kaur Provinsi Bengkulu pada Bulan September-Oktober 2017. Alat dan bahan yang digunakan dalam penelitian ini adalah kuesioner penelitian, alat tulis dan kamera. Metode penelitian adalah metode survei dengan metode deskriptif yang bersifat studi kasus, yakni membuat gambaran secara sistematis, faktual dan akurat mengenai fakta, sifat serta hubungan antar fenomena yang diteliti (Nazir, 2003).

Variabel yang diteliti adalah persepsi nelayan (terdiri atas 12 parameter pertanyaan) dan partisipasi nelayan (terdiri atas 10 parameter pertanyaan). Variabel persepsi nelayan selanjutnya dipisahkan dalam 3 kategori yaitu baik, sedang dan tidak baik. Begitu pula variabel partisipasi nelayan juga dibagi menjadi 3 kategori, yaitu aktif, pasif dan negatif (Ngakan, et. al., 2006)

Data yang dikumpulkan adalah data primer yakni data yang diperoleh dari informasi langsung dilapangan, baik melalui pengamatan, kuisioner dan hasil wawancara dengan responden. Data 
sekunder berasal dari monografi desa dan instansi terkait seperti UNIB, Dinas Perikanan, BPS dan BAPPEDA Kabupaten Kaur.

Populasi dalam penelitian ini adalah nelayan Desa Sekunyit dengan jumlah responden sebanyak 50 orang $(24,27 \%)$ dari jumlah penduduk yang berprofesi sebagai nelayan (206 orang). Hal ini sesuai dengan pendapat Gay dan Diehl (1992) yang menyebutkan bahwa jika penelitiannya bersifat deskriptif, maka sampel minimumnya adalah $10 \%$ dari populasi. Pemilihan responden dilakukan dengan metode purposive sampling.

Skala yang digunakan untuk mengukur persepsi dan partisipasi nelayan menggunakan skala likert. Data yang diperoleh dari kuesioner adalah data ordinal yang mengukur tingkatan dari sangat positif sampai sangat negative, maka jawaban diberi skor 1 sampai 4.

Analisa data menggunakan metode analisis deskriptif kuantitatif. Ukuran persepsi dan partisipasi nelayan dalam pengelolaan DPL dapat diketahui dengan menggunakan rumus yang digunakan Arafat (2010) sebagai berikut:

$$
\begin{aligned}
\text { UP }= & \sum X_{i j}(\text { ya }) \times 100 \% \\
\text { NS } &
\end{aligned}
$$

Keterangan:

UP : Ukuran persepsi/ partisipasi masyarakat

Xij : Jumlah nilai yang menjawab ya pertanyaan ke i dan responden ke-j

NS : Nilai sebenarnya/ seharusnya dari jawaban responden

Selanjutnya nilai UP dibagi menurut kategori sebagai berikut:

- Nilai UP > 66,68 \%: Persepsi Baik/ Partisipasi Aktif

- Nilai UP 33,34\% - 66,67 \%: Persepsi Sedang/ Partisipasi Pasif

- Nilai UP < 33,33 \%: Persepsi Tidak Baik/ Partisipasi Rendah (Negatif)

Menurut Ayunita dan Hapsari (2012) untuk menggambarkan hubungan antara tingkat persepsi dan tingkat partisipasi digunakan analisis distribusi frekuensi dengan tabulasi silang yang kemudian diuji dengan Chi Square sebagai berikut:

$$
X^{2}=\sum\left[\frac{\left(f_{0}-f_{\theta}\right)^{2}}{f_{e}}\right]
$$

Keterangan

$\mathrm{X}^{2}$ : Chi Square

$\mathrm{f}_{0} \quad$ : Besarnya frekuensi yang teramati pada kategori

$\mathrm{f}_{\mathrm{e}} \quad$ : Besarnya frekuensi yang diharapkan ada kategori tertentu

Hipotesis yang diajukan dalam Penelitian ini adalah:

Ho : Tidak ada hubungan yang signifikan antara persepsi dengan partisipasi nelayan dalam pengelolaan DPL Sekunyit.

$\mathrm{Ha}$ : Ada hubungan yang signifikan antara persepsi dengan partisipasi nelayan dalam pengelolaan DPL Sekunyit.

Ho:

Kriteria penerimaan dan penolakan

- Jika $X^{2}$ hitung $\leq X^{2}$ tabel maka Ho diterima

- Jika $X^{2}$ hitung $>X^{2}$ tabel maka Ho ditolak

Mengetahui derajat keeratan hubungan antara persepsi nelayan dengan partisipasi nelayan digunakan uji koefisien kontingensi dengan rumus Sudjana (1996):

$$
c=\sqrt{\frac{X^{2}}{X^{2}+n}}
$$

Keterangan

$\mathrm{C}=$ Koefisien Kontingensi

$\mathrm{X}^{2}=$ Nilai $\mathrm{X}^{2}$ hitung

$\mathrm{N}=$ Jumlah responden

Nilai C berkisar antara $0-1,00$ dan semakin besar nilai $\mathrm{C}$ berarti hubungan dua variabel makin erat. Pedoman untuk 
memberikan interpretasi Koefisien Kontingensi pada Tabel 1 berikut ini:

Tabel 1. The Value of Correlation Coefficient and Level of Relationship:

\begin{tabular}{ll}
\hline Rate Coefficient & Interval Relation \\
\hline $0,00-0,199$ & Sangat Rendah \\
$0,20-0,399$ & Rendah \\
$0,40-0,599$ & Sedang \\
$0,60-0,799$ & Kuat \\
$0,80-1,00$ & Sangat Kuat \\
\hline
\end{tabular}

Sumber Sugiyono (2007)

\section{HASIL DAN PEMBAHASAN}

Desa Sekunyit merupakan salah satu desa di Kecamatan Kaur Selatan yang terletak di bagian Barat Kabupaten Kaur yang berhadapan langsung dengan Samudera Hindia. Desa ini mempunyai luas $120 \mathrm{Ha}$. Penduduk Desa Sekunyit berjumlah 891 yang terdiri dari 401 jiwa laki-laki dan 490 jiwa perempuan. Jumlah penduduk Desa Sekunyit berdasarkan mata pencaharian berjumlah 376 jiwa dengan sebagian besar mata pencahariannya adalah nelayan (206 jiwa) sehingga dapat dikatakan bahwa tingkat ketergantungan masyarakat terhadap perikanan tangkap untuk menopang struktur ekonomi sangat tinggi. Masyarakat Desa Sekunyit umumnya mengoperasikan alat tangkapnya tidak jauh dari pantai jika menggunakan perahu tanpa motor. Daerah penangkapan ikan nelayan Desa Sekunyit pada umumnya terdapat di perairan sepanjang pantai Kabupaten Kaur hingga sejauh 4 mil dari garis pantai jika menggunakan perahu mesin tempel. Sebagian kecil nelayan Desa Sekunyit juga mempunyai armada penangkapan diatas $\geq$ 10 GT sehingga daerah penangkapannya bisa mencapai Pulau Enggano dan Lampung.

Pada tahun 2007 Bupati kaur telah mengeluarkan Surat Keputusan No. 180 tahun 2007 tentang penunjukkan Kawasan Linau, Merpas dan Sekunyit sebagai Kawasan Konservasi Laut Daerah (KKLD) Kabupaten Kaur. Potensi dari
KKLD Kaur ini adalah beragam biota laut yang berasosiasi dengan terumbu karang. Untuk mengoptimalkan upaya konservasi terumbu karang di Desa Sekunyit maka dibentuklah DPL pada tahun 2009.

Topografi dasar Perairan Sekunyit adalah flat, dengan kemiringan sekitar $15^{\circ}$. Secara umum terumbu karang di Perairan Sekunyit merupakan jenis terumbu karang tepi (Fringing reefs). Menurut Nybakken (1992) menyatakan terumbu karang tepi berkembang di sepanjang pantai dan mencapai kedalaman tidak lebih dari $40 \mathrm{~m}$. Purnama (2009) menyatakan kondisi tutupan terumbu karang di perairan Sekunyit termasuk dalam kategori sedang $(25-50 \%)$ dengan tutupan karang hidup yang ditemukan di Perairan Sekunyit terdiri dari Acropora (8 lifeform) dan Non Acropora (5 lifeform).

Penetapan suatu DPL tidak dapat dipisahkan dengan agenda besar pengelolaan wilayah pesisir terpadu di suatu daerah. Isu-isu pengelolaan pesisir, seperti penangkapan ikan yang merusak, degradasi habitat, kurangnya kesadaran masyarakat, penangkapan yang berlebih merupakan isu-isu yang berkaitan dengan pengelolaan suatu DPL. Penempatan DPL Sekunyit dengan memperhatikan sebaran terumbu karang yang akan dilindungi dan profil dasar perairan. Lokasi Daerah Perlindungan Laut di Desa Sekunyit terdapat pada S: $04^{0} 46^{\prime} 16^{\prime \prime}$ dan E: $103^{0} 19^{\prime} 04$ '. Dalam suatu kawasan DPL, masyarakat Desa Sekunyit membagi kawasan tersebut menjadi: zona inti, zona 
penyangga dan zona pemanfaatan. Zona inti merupakan suatu kawasan yang benarbenar tetutup dari segala bentuk aktifitas manusia dengan luasan $0.8 \mathrm{Ha}$. Zona penyangga merupakan zona barrier bagi zona inti dan hanya beberapa aktifitas tertentu yang dapat diperbolehkan pada kawasan tersebut dengan jarak 5 meter dari zona inti. Sementara zona pemanfaatan adalah kawasan selain zona inti dan zona penyangga.

\section{Persepsi Nelayan dalam PengeloLaan Daerah Perlindungan Laut Sekunyit}

Nelayan Desa Sekunyit mempunyai tingkat persepsi mengenai Terumbu Karang sebesar $84,5 \%$ dan tingkat persepsi mengenai Daerah Perlindungan Laut sebesar 74\%. Nelayan Desa sekunyit mengetahui letak posisi keberadaan Daerah Perlindungan Laut dengan persentase persepsi sebesar 71,5\%. Nelayan Desa sekunyit mengetahui letak Zona Inti Daerah Perlindungan Laut dengan nilai persepsi sebesar 64,5\%. Nelayan Desa Sekunyit mempunyai tingkat persepsi mengetahui aturan Daerah Perlindungan Laut sebesar 68,5\%. Nelayan Desa Sekunyit mempunyai tingkat persepsi terhadap aturan yang menyebutkan bahwa akan mendapatkan sanksi jika memasuki Zona Inti DPL sebesar 73\%. hal ini dikarenakan sebagian besar responden telah mengikuti sosialisasi yang dilakukan oleh pemerintah Provinsi Bengkulu bersama Program Mitra Bahari mengenai Daerah Perlindungan Laut Berbasis Masyarakat (DPL-BM) pada tahun 2009.

Hasil kuesioner juga menunjukkan bahwa Nelayan Desa Sekunyit mempunyai persepsi sebesar $87,5 \%$ tentang pentingnya Terumbu Karang bagi kehidupan mereka Persentase ini menunjukkan sebagian besar nelayan telah memahami tentang arti penting ekosistem terumbu karang. Menurut Bengen (2000), terumbu karang tepi berperan penting sebagai pelindung pantai dari hempasan ombak dan arus kuat yang berasal dari laut. Tanpa adanya terumbu karang akan banyak daratan yang terkikis oleh erosi. Fungsi lain ekosistem terumbu karang adalah sebagai daerah pemijahan (Breeding Grounds), daerah asuhan (Nursery Grounds), dan daerah mencari makan (Feeding Grounds) bagi berbagai jenis organisme laut. Sebagai salah satu habitat dengan kekayaan spesies yang tinggi, terumbu karang penting dalam memelihara keanekaragaman hayati dan sebagai sumber genetik. Terumbu karang tidak hanya menyediakan perlindungan fisik tetapi juga mendukung secara biologi kepada padang lamun, mangrove dan laut terbuka tetapi juga mendukung jejaring makanan pelagis.

Zona Inti DPL Nelayan Desa sekunyit mempunyai tingkat persepsi sebesar 66\%. Zona Inti Merupakan area yang memiliki nilai konservasi tinggi yang sangat rentan terhadap gangguan dari luar sehingga diupayakan seminimal mungkin intervensi manusia dan harus mendapat perlindungan yang maksimum dalam proses pengelolaannya.

Nelayan Desa Sekunyit mempunyai tingkat persepsi sebesar $70 \%$ terhadap manfaat DPL dan mempunyai nilai persepsi sebesar $84 \%$ terhadap keberadaan DPL yang perlu di pertahankan atau di lestarikan. hal ini menunjukkan bahwa sebagian besar responden telah menyadari arti pentingnya pengelolaan DPL sebagai sumber kehidupan masyarakat yang berkelanjutan. Persepsi Nelayan Sekunyit tentang bentuk sanksi yang diberikan jika memasuki Zona Inti DPL sebesar 55,5\%. 


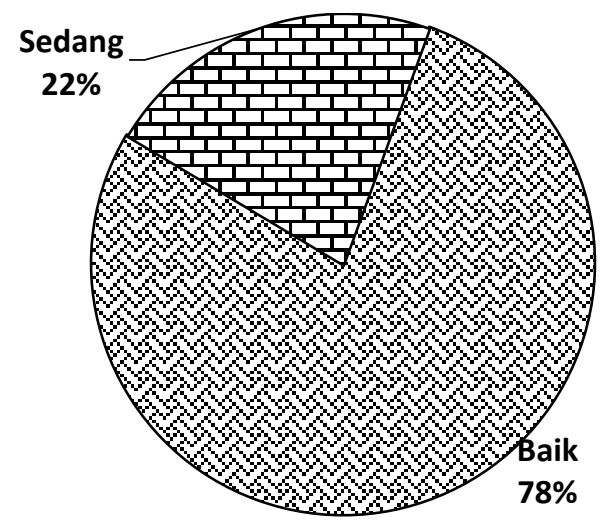

Gambar 1. Kategori Persepsi Nelayan dalam Pengelolaan DPL Sekunyit

Berdasarkan tabulasi jawaban responden terhadap kuesioner mengenai persepsi nelayan dalam pengelolaan Daerah Perlindungan Laut Sekunyit Nelayan Desa Sekunyit pada umumnya mempunyai persepsi yang termasuk dalam kategori baik $(72,42 \%)$. Jika dilihat dari Gambar 1. juga didapatkan informasi bahwa $78,0 \%$ responden berada pada kategori tingkat persepsi baik dan 22,0\% responden berada pada kategori tingkat persepsi sedang.

\section{Partisipasi Nelayan dalam Pengelolaan Daerah Perlindungan Laut Sekunyit}

Partisipasi adalah pengambilan bagian atau pengikutsertaan, dimana orang diikutsertakan dalam suatu perencanaan serta dalam pelaksanaan dan juga ikut memikul tanggung jawab sesuai dengan tingkat kematangan berpikir dan tingkat kewajibannya.

Nelayan Desa Sekunyit sebesar $78 \%$ menilai bahwa Program DPL ini tidak mengganggu waktu kerja nelayan sekunyit. Nelayan Desa Sekunyit mempunyai tingkat partisipasi sebesar 97 $\%$ terhadap pelestarian Terumbu Karang dengan tidak melakukan kegiatan eksploitasi Terumbu Karang. Hal ini dikarenakan mereka telah memahami arti pentingnya terumbu karang sebagai rumah ikan sehingga apabila terumbu karang rusak maka ikannya banyak sekali yang berkurang. Pada penentuan zona inti DPL nilai partisipasi nelayan sebesar $52,5 \%$ yang terdiri.

Nelayan Desa Sekunyit mempunyai tingkat partisipasi sebesar $53 \%$ dalam kegiatan musyawarah yang diadakan oleh POKMASWAS (Kelompok Masyarakat Pengawas) kelautan dan perikanan selama 1 tahun terakhir. Tingkat partisipasi Nelayan Desa Sekunyit dalam kegiatan pengawasan sumberdaya kelautan dan perikanan yang berada di DPL Sekunyit dalam 1 tahun terakhir sebesar 58,5\%. Keterlibatan mereka selain dalam kegiatan fisik juga dalam pertemuan-pertemuan yang membahas mengenai rencana kegiatan kelompok. Juga diperlukan pengawasan dan penindakan yang tegas terhadap masyarakat yang masuk kezona inti baik dari POKMASWAS, pemerintah desa dan aparat terkait. Menurut Peraturan Desa Sekunyit Nomor 02/Oktober/2009 Barang siapa yang memasuki zona inti dan zona penyangga akan di berikan teguran dan sanksi.

Tingkat partisipasi Nelayan Desa Sekunyit dalam mengeluarkan pendapat pada pelatihan-pelatihan untuk mendukung kegiatan DPL sebesar 68\%. Nelayan Desa Sekunyit mempunyai tingkat partisipasi 
dalam mengembangkan usaha mata pencaharian alternatif sebesar $70 \%$.

Partisipasi Nelayan Sekunyit untuk tidak menangkap ikan di Zona Inti sebesar $81,5 \%$. Beberapa orang yang pernah menangkap ikan di zona inti tersebut merupakan oknum nelayan tidak mempunyai komitmen terhadap aturan DPL dan kelestarian terumbu karang di Perairan Sekunyit. Kegiatan musyawarah dan diskusi mengenai DPL Sekunyit harus terus dilakukan sehingga kesadaran akan penting DPL ini terus meningkat.

Nelayan Desa Sekunyit sebesar 70\% berpartisipasi untuk tidak pergi ke DPL untuk menangkap ikan dan beranggapan hal tersebut tidak mengganggu jumlah tangkapan mereka. Pada umumnya kelompok nelayan ini mencari ikan di luar Zona Inti DPL, mereka sadar akan pentingnya keberadaan DPL. Keberadaan DPL ini dalam waktu singkat memang belum menunjukkan hasil akan tetapi akan terlihat dampaknya dalam waktu yang cukup lama. Dengan keberadan DPL maka stok ikan di perairan sekunyit akan terus ada. Karena ikan di wilayah DPL di beri kesempatan untuk tumbuh dan berkembang biak dan terumbu karang sebagai rumah bagi ikan di jaga keberadaannya.

Tingkat Partisipasi Nelayan Desa Sekunyit untuk tidak terlibat dalam kegiatan destruktif fishing sebesar 79\%. Responden umumnya mengetahui resiko dari kegiatan destruktif fishing, yaitu: risiko terhadap manusia itu sendiri dan populasi ikan akan berkurang serta terumbu karang akan hancur. Masyarakat menyadari arti penting kawasan DPL sebagai kawasan ekosistem yang perlu dijaga karena memberikan manfaat dalam kelestarian sumberdaya ikan. Bentuk partisipasi lainnya dapat juga dilihat dari jenis alat tangkap yang digunakan oleh responden yang menggunakan alat tangkap yang ramah lingkungan. Lokasi DPL yang berdekatan dengan pemukiman lebih memungkinkan pengawasan yang baik, sehingga aktifitas destructive fishing bisa ditekan. Dahuri et. al., (2001) menyatakan bahwa kerusakan terumbu karang umumnya disebabkan oleh kegiatan perikanan yang bersifat destruktif, yaitu penggunaan bahan peledak, sianida dan aktivitas penambangan karang untuk bahan bangunan, penambatan jangkar perahu serta akibat sedimentasi. Sebagian dapat juga terjadi secara alami, yaitu pengaruh iklim global dan dimangsa biota laut serta rusak akibat penggunaan Trawl.

Berdasarkan jumlah responden di dapatkan kategori partisipasi nelayan seperti terlihat pada Gambar 2.

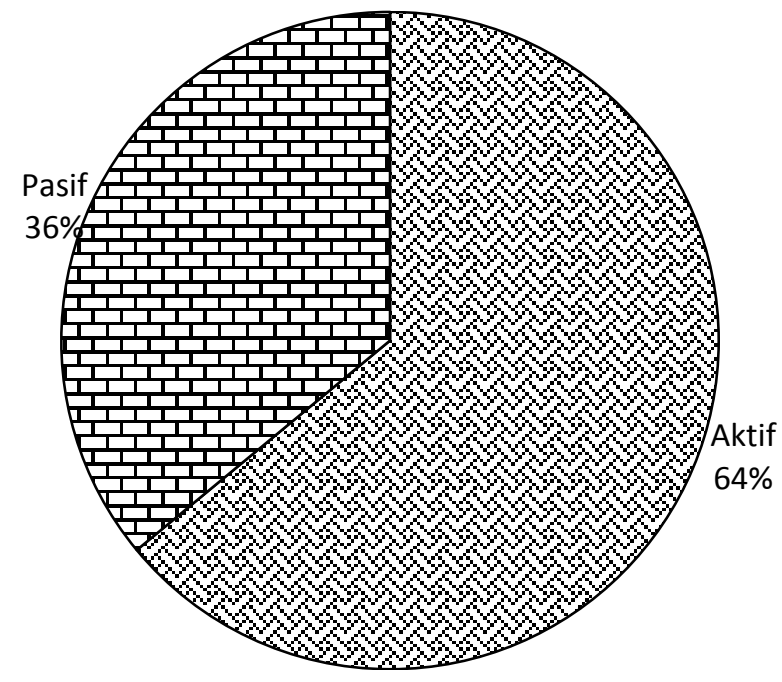


Gambar 2. Kategori Partisipasi Nelayan dalam Pengelolaan DPL Sekunyit

Partisipasi masyarakat dalam pengelolaan ekosistem terumbu karang di DPL Sekunyit dipandang sangat penting. Keterlibatan masyarakat secara aktif baik moril maupun materiil diperlukan dalam pengelolaan DPL. Nelayan Desa Sekunyit mempunyai tingkat partisipasi yang termasuk kategori Aktif sebesar 70,10\%. Gambar 2. memberikan informasi bahwa dari 50 responden yang diteliti, 64,0\% responden tingkat partisipasinya aktif dan sebanyak $36,0 \%$ responden tingkat partisipasinya pasif.

\section{Hubungan Persepsi terhadap Partisipasi Nelayan dalam Pengeloaan DPL Sekunyit}

Hasil tabulasi silang antara persepsi dan partisipasi nelayan dapat diketahui bahwa responden dengan tingkat persepsi baik dan tingkat partisipasi aktif sebanyak 54\% responden, sedangkan tingkat persepsi baik dan tingkat partisipasi pasif sebanyak 24\% responden. Responden dengan tingkat persepsi sedang dan tingkat partisipasi aktif sebanyak $10 \%$ responden, sedangkan tingkat persepsi sedang dan tingkat partisipasi pasif sebanyak 12\% responden. Berdasarkan hasil Uji Chi Square dapat diketahui bahwa nilai $\mathrm{X}^{2}$ hitung 2,105 $<\mathrm{X}^{2}$ tabel 3,841 maka Ho diterima dan Ha ditolak. Sehingga dapat diketahui bahwa tidak ada hubungan yang signifikan antara persepsi nelayan terhadap partisipasi nelayan dalam pengelolaan DPL Sekunyit. Hasil nilai uji koefisien kontingensi 0,201 sehingga Derajat keeratan hubungan antara persepsi nelayan dengan partisipasi nelayan Desa Sekunyit pada kategori rendah.

Hal ini berbeda dengan penelitian yang dilakukan Mardijono (2008) dimana diperoleh kesimpulan hubungan yang sangat erat antara persepsi masyarakat dengan partisipasi masyarakat terhadap pengelolaan KKLD Kota Batam dan penelitian yang dilakukan oleh Ayunita dan Hapsari (2012) yang mendapatkan hasil dimana hubungan antara persepsi dan tingkat partisipasi masyarakat pesisir cukup kuat dalam kegiatan pengelolaan KKLD di Ujungnegoro. Keadaan ini dapat di jelaskan karena partisipasi masyarakat selain di pengaruhi oleh persepsi juga di pengaruhi oleh faktor-faktor lain. Mardijono (2008) dalam penelitiannya menyebutkan terdapat hubungan antara peran pemerintah dengan partisipasi masyarakat dalam pengelolaan KKLD Kota Batam. Peran pemerintah mampu mendorong sikap masyarakat dalam berpartisipasi aktif dalam pengelolaan DPL. Selain itu Rauf (2008) menyatakan bahwa partisipasi dipengaruhi oleh faktorfaktor sebagai berikut: konteks sosial ekonomi, teknologi dan produktivitas, serta organisasi sosial dan kelembagaan. Salim et. al., (2014) menyatakan partisipasi dipengaruhi oleh sikap..

Melalui penelitian ini beberapa hal penting yang perlu dilakukan kedepanya yaitu untuk penegakkan hukum, secara yuridis formal status peraturan desa yang telah ditetapkan oleh desa agar memiliki kekuatan hukum yang tetap. Masih terpola sebuah pemikiran yang klasik bahwa penegakkan aturan akan efektif jika tindakan atas pelanggaran peraturan yang ditetapkan bersama oleh masyarakat di tingkat desa harus dilakukan oleh intitusi formal seperti polisi/ angkatan laut. Selain itu pengelolaan DPL dipengaruhi juga oleh masalah pendanaan. Dalam pengelolaan DPL, dana dibutuhkan untuk melaksanakan pertemuan, penggantian tanda batas pelampung (rambu-rambu DPL), biaya operasional pengawasan. Secara umum kondisi fisik seperti ramburambu DPL sudah tidak terlihat lagi sehingga tidak menunjukkan fungsi sebagai tanda batas Zona Inti DPL. Hal yang terpenting diharapkan bahwa masyarakat lokal memiliki kontribusi penuh pengelolaan dari Daerah 
Perlindungan Laut ini. Dengan demikian mereka akan mengambil tanggung jawab KESIMPULAN

1. Nelayan Desa Sekunyit mempunyai tingkat persepsi baik $(72,42 \%)$ dan tingkat partisipasi aktif $(70,10 \%)$ dalam pengelolaan Daerah Perlindungan Laut Sekunyit.

2. Tidak ada hubungan yang signifikan antara persepsi dengan partisipasi nelayan dalam pengelolaan Daerah Perlindungan Laut Sekunyit. Hubungan persepsi nelayan dengan partisipasi nelayan mempunyai derajat keeratan yang termasuk kategori rendah. Sikap masyarakat dan peranan pemerintah menjadi faktor yang mempengaruhi keberhasilan suatu DPL.

\section{DAFTAR PUSTAKA}

Arafat, M.Y. 2010. Persepsi dan Partisipasi Masyarakat Desa TaboTabo terhadap Program Pemberdayaan Masyarakat di Kawasan Hutan dengan Tujuan Khusus (KHDTH) Balai Diklat Kehutanan Makassar. Tesis. Program Pasca Sarjana Studi SistemSistem Pertanian Universitas Hasanuddin. Makassar..

Ayunita, D., dan T. D. Hapsari. 2012. Analisis Persepsi dan Partisipasi Masyarakat Pesisir pada Pengelolaan KKLD Ujungnegoro, Kabupaten Batang. Jurnal SEPA : Vol. 9 (1): $117-124$.

Bengen, D.G. 2000. Sinopsis Ekosistem Sumberdaya Pesisir. Pusat Kajian Sumberdaya Pesisir dan Lautan. Institut Pertanian Bogor. Bogor.

Dahuri, R.,J. Rais, S.P. Ginting, dan M.J. Sitepu. 2001. Pengelolaan Sumberdaya Wilayah Pesisir dan Lautan secara Terpadu. PT Pradnya Paramitha. Jakarta.

Gay, L.R. and Diehl, P.L. 1992. Researh Methods for Business and di dalam menjaga sumberdaya alam yang mereka miliki.

Managemen. Macmillan Publishing Company. New York.

Mardijono. 2008. Persepsi dan Partisipasi Nelayan terhadap Pengelolaan Kawasan Konservasi Laut Kota Batam. Tesis Pasca Sarjana Universitas Diponegoro..

Nazir, M. 2003. Metode Penelitian. Penerbit Ghalia Indonesia. Jakarta.

Nybakken, J.W. 1992. Biologi Laut Suatu Pendekatan Ekologis. diterjemahkan oleh H.M. Eidman, Koesoebiono, D.G. Bengen, M. Hutomo dan S. Sukaedjo. PT. Gramedia, Jakarta Indonesia.

Purnama, D. 2009. Daerah Perlindungan Laut Berbasis Masyarakat (DPLBM) di Desa Sekunyit Kabupaten Kaur. Penelitian Prodi Ilmu Kelautan UNIB. Bengkulu.

Rauf, A. 2008. Pengembangan Terpadu Pemanfaatan Ruang Kepulauan Tanakeke Berbasis Daya Dukung. Disertasi Program Studi Ilmu Pengelolaan Sumberdaya Pesisir dan Lautan Departemen Manajemen Sumberdaya Perairan Sekolah Pascasarjana Institut Pertanian Bogor. Bogor.

Salim, D., Y. Wardiatno dan L. Adrianto. 2014. Efektifitas Pengelolaan Daerah Perlindungan Laut (Studi Kasus Desa Mattiro Labangeng Kabupaten Pangkep. Jurnal Kelautan Volume 7, No 2, Oktober 2014.

SK Bupati Kabupaten Kaur No. 180 Tahun 2007 tanggal 20 Juni 2007 tentang penetapan kawasan Linau, Merpas, dan Sekunyit sebagai Kawasan Konservasi Laut Daerah (KKLD) di Kabupaten Kaur.

Sudjana. 1996. Metoda Statistika. Penerbit Tarsito. Bandung.

Sugiyono. 2007. Metode Penelitian Pendidikan, Pendekatan Kuantitatif, Kualitatif dan R\&D. Penerbit Alphabeta. Bandung. 
P-ISSN: 2302- 6715

E- ISSN: 2654-7732

Tulungen J, Bayer. T, Dimpudus. M, Kasmidi. M, Rotinsulu. C, Sukmara. A, Tangkilisan. N. 2003. Panduan Pembentukan dan Pengelolaan Daerah Perlindungan laut Berbasis Masyarakat. Departemen Kelautan dan Perikanan. Jakarta. 